\title{
KONSTRUKSI MEDIA PADA POLITIKUS WANITA: JUDUL PEMBERITAAN KASUS HOAKS TOKOH POLITIK PEREMPUAN DI MEDIA MASSA ONLINE INDONESIA
}

\author{
Rai Bagus Triadi' ${ }^{1}$ Firman Aziz ${ }^{2}$ \\ ${ }^{1}$ Universitas Pamulang \\ ${ }^{2}$ Universitas Pendidikan Indonesia \\ 1'molikejora12@gmail.com, ${ }^{2}$ firman.aziz@upi.edu
}

\begin{abstract}
Abstrak
Pada pertengahan bulan September 2019, warga Indonesia dikagetkan dengan kasus hoaks tokoh politik dan seniman Indonesia, Ratna Sarumpaet. Kasus tersebut lambat laun bergeser ke motif politik yang ada di balik situasi politik Indonesia. Berdasarkan hal tesebut penelitian ini berusaha mendeskripsikan gambaran politikus wanita pada kasus hoaks Ratna Sarumpaet dengan menggunakan teori analisis wacana kritis. Penelitian ini menggunakan metode studi kasus bentuk tunggal pendekatan kualitatif dengan perspektif kritis tentang penggambaran sebenar-benarnya politisi wanita pada pemberitaan kasus hoaks di berbagai media online. Studi kasus politisi wanita yang digunakan adalah Ratna Sarumpaet, seorang seniman berkebangsaan Indonesia yang banyak menggeluti dunia panggung teater sekaligus aktivis organisasi sosial Ratna Sarumpaet Crisis. Penelitian dilakukan tiga bulan dengan data diambil dari media massa online di Indonesia dengan cara purposive sampling. Ada lima data pemberitaan dari berbagai media online yang berbeda dengan waktu yang berbeda-beda pula. Hasil analisis menunjukkan terdapat upaya penggiringan opini terhadap masyarakat tentang keterlibatan salah satu paslon dengan kasus hoaks yang dilakukan oleh tokoh politik ratna sarumpaet. Hal ini dilakukan untuk menurunkan dukungan politik jelang pemilihan presiden 2019.
\end{abstract}

Kata Kunci: Media, Kontruksi Media, Hoaks, Politikus Wanita, Critical Discourse Analysis (CDA)

\begin{abstract}
In mid-September 2019, Indonesians were surprised by the case of Indonesian political figures and artists, Ratna Sarumpaet. The case gradually shifted to the political motives behind Indonesia's political situation. Based on these things, this study seeks to describe the description of female politicians in the case of Ratna Sarumpaet's hoax using the theory of critical discourse analysis. This study uses a case study method in the form of a single qualitative approach with a critical perspective on the actual depiction offemale politicians in reporting hoax cases in various online media. The case study of the female politician used was Ratna Sarumpaet, an Indonesian artist who had a lot of interest in the theater scene, in addition to being an activist for the social organization Ratna Sarumpaet Crisis. The study was conducted in three months with data taken from online mass media in Indonesia by purposive sampling. There are five news data from various online media that are different from different times. The results of the analysis show that there was an attempt to convince opinion about the community about the involvement of one candidate pair with a hoax case carried out by political figure Ratna Sarumpaet. This was done to reduce political support ahead of the 2019 presidential election.
\end{abstract}

Keywords: Media, Media Construction, Hoaks, Women's Politicians, Critical Discourse Analysis (CDA) 


\section{PENDAHULUAN}

Penggunaan dan pemilihan diksi secara kias pada judul pemberitaan sering dilakukan oleh media massa di Indonesia. Hal tersebut dilakukan untuk memberikan nilai rasa atau emosi yang berbeda pada saat masyarakat membaca judul suatu pemberitaan. Judul berita dalam ruang lingkup berita secara umum dapat diibaratkan sebagai sebuah topeng yang dipasangkan oleh penulis, dapat berupa topeng yang cantik dan menarik, atau topeng yang buruk dan menyeramkan.

Pada berbagai pemberitaan kasus yang terkait dengan pihak wanita terkadang media massa di Indonesia menyudutkan wanita sebagai objek (textual interrogation), terlebih jika kasusnya berbentuk kekerasan atau seksual. Wolf (tahun); Sunarto (2009); menyatakan media massa mempunyai potensi sebagai pemicu munculnya bentuk bentuk realitas ketimpangan hubungan sosial (social relationships (baca: kekerasan)) dalam kehidupan bermasyarakat. Sosok wanita oleh media massa, baik melalui iklan maupun beritanya, selalu dideskripsikan secara negatif dan sangat tipikal yaitu tempatnya wanita ada di rumah, berperan tunggal sebagai ibu rumah tangga dan pengasuh, tergantung pada pria, menjalani profesi secara terbatas, tidak mampu membuat keputusan penting, selalu melihat dirinya sendiri, sebagai objek seksual/ simbol seks (sexploitation, pornographizing), objek peneguhan pola kerja patriarki, objek fetish, objek pelecehan dan kekerasan, selalu disalahkan (blaming the victim) dan bersikap pasif, serta sebagai alat pembujuk/negosiasi. Eksistensi wanita tidak terwakili pula secara proporsional di media massa, baik dalam industri media hiburan maupun dalam industri media berita.
Pada penelitian ini, peneliti melihat penggambarkan oleh berbagai media massa, khususnya media online tentang kasus kebohongan yang dilakukan oleh sosok wanita yang di sini berperan sebagai tokoh masyarakat atau tokoh politik yang seharusnya memberikan contoh dan kesan yang baik terhadap gambaran wanita di dunia sosial dan politik. Tokoh tersebut adalah Ratna Sarumpaet, selain tokoh politik, beliau dapat dikatakan sebagai tokoh masyarakat. Hal ini dikarenakan keaktifannya dalam berbagai bidang, seperti seniman teater, penulis naskah, sutradara, bahkan seorang aktivis HAM.

Pada proses studi awal penelitian ini, peneliti menemukan salah satu contoh judul pemberitaan pada laman m.liputan6.com yang berjudul Prabowo dan Residu Dusta Ratna Sarumpaet. Berita ini dikeluarkan di laman pada 9 Oktober 2018, pukul 00.03 WIB. Apabila dianalisis secara mendasar, pada judul berita tersebut muncul kata kias residu yang diartikan dalam KBBI sebagai ampas; endapan (tt minyak tanah, gula, dsb). Ampas tersebut dapat diinterprestasikan sebagai ampas yang dibuat mengendap atau tidak sengaja diendapkan. Selain itu, penggunaan konjungsi dan pada judul berita tersebut menggiring opini masyarakat bahwa sosok Prabowo terkait dengan kebohongan yang dilakukan Ratna Sarumpaet. Hal tersebut disebabkan, penggunaan konjungsi dan mempunyai fungsi sebagai penghubungan satuan bahasa yang setara, termasuk tipe yang sama serta memiliki fungsi yang tidak berbeda. Hal tersebut akan berbeda, ketika penulisan judul menggunakan fungsi yang tidak setara atau subordinatif.

Berdasarkan relasional tekstual, judul pemberitaan tersebut mengkaitkan antara tokoh publik (yang sedang diperbincangkan) dengan sebuah 
peristiwa buruk dan seorang tokoh (dalam hal ini mendukung tokoh publik tersebut) menjadi sesuatu yang bersifat saling memiliki keterkaitan, direncanakan dan bukan karena faktor ketidaksengajaan.

Setelah melihat hasil studi pendahuluan tersebut, peneliti menetapkan masalah yang akan dibahas pada penelitian ini meliputi, 1) pemilihan diksi judul dan isi pemberitaan pada tataran frasa, klausa, hingga kalimat. 2) relasional tekstual dan isu-isu politik terkait yang akhirnya memberikan simpulan tentang penggambaran politisi wanita di media massa online.

Teori yang digunakan untuk mendeskripsikan rumusan masalah yang pertama digunakan teori Critical Discourse Analysis Norman Fairclough, sedangkan teori yang dipakai untuk menjelaskan rumusan masalah yang kedua digunakan teori ideologi Raymond William dan Louis Althusser. Adapun penjelasan masing-masing teori tersebut sebagai berikut.

Fairclough dalam (Darma, 2009:69) menjelaskan wacana harus dipandang secara simultan, yaitu sebagai (1) teks-teks bahasa, baik lisan maupun tulisan, (2) praksis kewacanaan, yaitu produksi teks dan interpretasi, (3) praksis sosiokultural, yaitu perubahanperubahan masyarakat institusi budaya yang menentukan bentuk dan makna sebuah wacana. Ketiga unsur itu, oleh Fairclough disebut "dimensi wacana", menganalisis wacana secara kritis pada hakikatnya adalah menaganalisis tiga dimensi wacana secara integral dan ketiga dimensi tersebut merupakan satu kesatuan yang tak dapat dipisahkan antara satu dengan yang lainnya. Konsep teori ini menurut peneliti sejalan dengan konsep elemen tindak tutur wartawan yang disampaikan oleh Geofreey Leech (tahun); siapa lagi (tahun); jurnal gema online; Wibowo (2009) yang membagi menjadi tiga hal, yaitu lokusi, ilokusi dan perlokusi. Adapun penjelasan konsep elemen tersebut terlihat pada tabel di bawah ini.

Tabel 1 Elemen Tindak Tutur Komunikasi Wartawan

\begin{tabular}{|c|c|}
\hline $\begin{array}{l}\text { Elemen } \\
\text { lokusi; } \\
\text { kategorisasi } \\
\text { dan ideology }\end{array}$ & $\begin{array}{lr}\text { Ungkapan } & \text { bahasa } \\
\text { adalah } & \text { wujud } \\
\text { antroposentrisme } \\
\text { individu, } & \text { yang } \\
\text { dilandasi } & \text { oleh } \\
\text { persepsi, } & \text { makna } \\
\text { niatan, } & \text { dan } \\
\text { kategorinya, } & \text { bahkan } \\
\text { juga } & \text { oleh } \\
\text { profesionalitasnya. }\end{array}$ \\
\hline $\begin{array}{l}\text { Elemen } \\
\text { ilokusi; tata } \\
\text { permainan } \\
\text { bahasa dan } \\
\text { implikasi } \\
\text { etisnya }\end{array}$ & $\begin{array}{lr}\text { Ungkapan } & \text { bahasa } \\
\text { adalah pernyataan } \\
\text { individu } & \text { tentang } \\
\text { sesuatu } & \text { yang } \\
\text { disampaikannya } \\
\text { melalui suatu daya } \\
\text { khas, yang membuat } \\
\text { individu tersebut } \\
\text { merasa telah bertindak } \\
\text { sesuai dengan apa } \\
\text { yang dilakukannya. } \\
\text { Oleh r karena } \\
\text { mengandung suatu } \\
\text { daya yang khas, suatu } \\
\text { ungkapan bahasa } \\
\text { selalu berimplikasi } \\
\text { dengan masalah etis. }\end{array}$ \\
\hline $\begin{array}{l}\text { Elemen } \\
\text { perlokusi; } \\
\text { efek } \\
\text { ungkapan } \\
\text { jurnalistik }\end{array}$ & 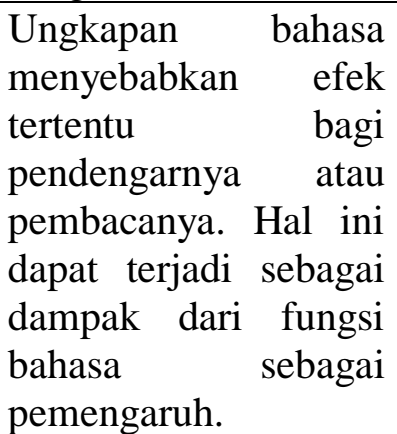 \\
\hline
\end{tabular}

Wacana selalu terkait dengan media massa. Hal tersebut dikarenakan media sebagai ruang di mana berbagai ideologi penulis atau jurnalis 
dipresentasikan. Secara tidak langsung media dapat menjadi sarana penyebaran ideologi penguasa, alat legitimasi, dan kontrol atas sebuah wacana publik. Hal ini makin menjadi ketika tahun politik dimulai, sudah bukan rahasia umum lagi ketika media massa, khususnya media massa televisi sudah tidak dapat bersifat netral terhadap situasi politik yang terjadi di Indonesia. Hal ini diakibatkan pemilik atau orang-orang yang menduduki posisi penting pada media massa tersebut berkecimpung di dunia politik, terlebih lagi secara terangterangan mendukung salah satu kelompok politik.

Berkaitan dengan hal tersebut, peneliti juga mengamati tentang sikap netral yang dimiliki oleh media massa online terhadap proses pemberitaan kasus tokoh politik hoaks Ratna Sarumpaet. Hal ini dikaitkan dengan beberapa media online yang ada masih memiliki relasi dengan media massa yang ada di televisi. Hasil pengamatan tersebut nantinya dapat menjadi sebuah temuan tentang jenis media massa online yang masih memiliki sikap netral dalam memberitakan pemberitaan yang bersifat politis.

Berkaitan dengan ideologi penulis, Althuseer dalam (Fiske, 1990) Menjelaskan konsep tentang subjek dan ideologi. Beliau memandang Ideologi selalu memerlukan subjek, sebaliknya subjek pasti memerlukan ideologi. Ideologi muncul berdasarkan hasil rumusan individu-individu tertentu, tetapi keberlakuannya menuntut tidak hanya kelompok yang bersangkutan. Penulis adalah sebuah individu, pengendalian pikiran-perasaan seseorang hanya dapat dilakukan oleh individu atau kelompok dominan. Bahasa harus dipahami tidak sekadar alat interaksi, tetapi juga transaksi (Brown dan Yule, 1996).
Teori ideologi Raymond William dan Louis Althusser dapat diartikan sebagai sebuah ideologi yang memandang bahwa makna homogen itu muncul lewat proses yang aktif dan dinamis, baik dari sisi penulis maupun pembaca. Pembaca dan teks berita secara bersama-sama mempunyai andil yang sama dalam memproduksi pemaknaan. Hubungan tersebut menempatkan pembaca sebagai satu bagian dari hubungannya dengan sistem tata nilai makna yang lebih besar di mana dia hidup pada sebuah lingkungan masyarakat.

Teori ideologi tersebut dapat dikaitkan secara langsung dengan konsep hegomoni Antonio Gramsci. Gramsci dalam (Setiawan, 2011: 15) mengkonstruksi suatu teori yang menekankan bagaimana penerimaan kelompok yang didominasi oleh kehadiran kelompok dominan berlangsung dalam suatu proses yang damai, tanpa tindakan kekerasan. Media massa dapat menjadi sarana di mana satu kelompok mengukuhkan posisinya dan merendahkan kelompok lainnya. Hal ini bukan berarti media merupakan perwujudan kekuatan jahat yang secara sengaja merendahkan masyarakat kelas bawah. Gambaran pernyataan teori tersebut sangatlah relevan dengan kondisi politik yang terjadi di Indonesia sekarang ini. Seperti yang telah dipaparkan peneliti sebelumnya, bahwa media massa saat ini menjadi sebuah alat mengukuhkan kedudukan pasangan calon yang sedang menduduki kekuasaan. Hal ini secara tidak langsung akan merendahkan pasangan calon yang menjadi lawan politiknya.

Kress (1984) menyatakan from the preceding argument it is clear that rewriting is more than a mere tinkering with language. Rewriting is a shorthand term for a process which involves at least these stages: the deconstruction in text, 
the reconstruction of the original event, its apperception in terms of the new schema. Both writing and rewriting are practices which are firmly set in ideological structures and are expressions of them. Peneliti mengambil tiga gagasan Kress dalam menghadapi teks berita di media massa. Pertama yaitu pada tahapan re-reporting dan rewriting atau bisa dikatakan struktur bahasa dan ideologisasi yang beriringan; kedua, ideologi yang muncul bisa dilihat ketika konteks yang utuh terlihat pada keseluruhan teks; dan ketiga, ideologi yang digunakan akan tampak ketika teks tersebut dikontruksi menggunakan struktur bahasa yang mana (pemilihan diksi).

Ansori (2017) menyatakan bahwa salah satu fungsi bahasa adalah sebagai kontrol sosial, yaitu kemampuan bahasa dalam mempengaruhi pikiran orang lainkarena pengunaan bahasa. Pencitraan terjadi karena perluasan pengaruh yang dilakukan oleh penutur sebuah bahasa. Kalimat-kalimat yang ditulis media akan berpengaruh di masyarakat, bahkan mungkin dianggap sebuah kebenaran. Heryanto (1996) dalam Ansori (2017) berpendapat bahasa tidak hanya dibentuk dan ditentukan, tetapi juga membentuk dan menentukan sejarah sosial. Bahasa bukan sekadar "alat" untuk mengungkapkan pikiran dan tidak mampu memenuhi kebutuhan komunikasi personal tidaklah layak jadi kekuatan pembemtuk pikiran-perasaan dan suatu tata sosial yang sebelumnya tidak ada. Bagaimana proses sejarah sosial yang mendorong perubahan dari masyarakat berbahasa ke masyarakat berbahasa.

\section{METODE PENELITIAN}

Penelitian ini menggunakan metode studi kasus bentuk tunggal dengan pendekatan kualitatif. Sumber data penelitian ini adalah berbagai tulisan meliputi judul dan isi pada media massa online yang memuat pemberitaan kasus hoaks tokoh politik Ratna Sarumpaet. Penelitian diklakukan selama tiga bulan dengan cara mengambil data dari media massa online Indonesia.

Pada penelitian ini data diambil dari berbagai sumber media massa online yang berbentuk laman. Peneliti mencari data kedekatan judul berita antara subjek tokoh politik Ratna Sarumpaet dengan tokoh politik yang menjadi sasaran media massa yaitu Prabowo Subianto. Setelah beberapa judul didapat peneliti mengklasifikasikan data berdasarkan kecurigaan peneliti terhadap pemilihan diksi penulis berita yang menjadi alat penggiring ideologi politik.

Waktu penelitian ini berjalan selama tiga bulan, tepatnya pada bulan November 2018 sampai Januari 2019. Bulan pertama dan kedua, peneliti melakukan proses pengumpulan data. Selain itu, mengamati perubahan berita berdasarkan perkembangan kasus kebohongan yang dilakukan oleh Ratna Sarumpaet. Perubahan berita tersebut berdampak langsung pada proses analisis yang melihat konteks berita dengan konteks keadaan politik pada saat itu.

Analisis data kualitatif yang dipakai dalam penelitian ini adalah Critical Discourse Analysis Norman Fairclough. Fairclough dalam (Krolokke dan Sorensen, 2006: 52-53) menyatakan proses analisis texts ini sebagai microlevel, discourse practice sebagai mesolevel dan proses analisis sociocultural practice sebagai macrolevel.

Menurut Fairclough, analisis teks ini disebut pula dengan linguistic analysis. Teks di sini dianalisis secara linguistik, dengan melihat kosakata, semantik dan tata kalimat. Fairclough juga memasukkan koherensi dan kohesi 
antarkata atau antarkalimat sehingga membentuk pengertian dalam sebuah wacana.

Kaitannya dengan penelitian ini, semua tataran linguistik yang dianalisis tersebut dipakai untuk melihat beberapa masalah antara lain, Ideasional atau representasi yang merujuk pada representasi tertentu yang ingin ditampilkan dalam judul dan isi yang secara tidak langsung membawa muatan politis tertentu. Representasi tersebut menurut Fairclough ditelaah dalam tiga hal tentang bagaimana seseorang, kelompok, dan gagasan ditunjukkan dalam kalimat, dalam kombinasi kalimat serta dalam rangkaian antarkalimat. Untuk representasi dalam anak kalimat, pemakai bahasa oleh penulis judul dan isi berita dihadapkan pada dua pilihan. Pertama, pada tingkat pilihan diksi.
Kedua, pilihan yang didasarkan pada tingkat tata bahasa. Ketiga konteks ditampilkan sebagai sebuah tindakan, peristiwa, keadaan, atau hanya sebagai proses mental.

\section{HASIL DAN PEMBAHASAN}

Berdasarkan pengumpulan data yang telah dilakukan, peneliti menemukan 10 data yang memiliki kedekatan antara judul dan isi pemberitaan kasus lancung tutur Ratna Sarumpaet di berbagai media massa online. Tabel data pada penelitian ini digunakan untuk mempermudah klasifikasi data penelitian. Judul pemberitaan diberikan koding berdasarkan urutan waktu pemberitaan dan urutan pemerolehan data. Adapun data tersebut terlampir pada tabel berikut ini.

Tabel 2 Data Penelitian

\begin{tabular}{|l|l|l|l|l|}
\hline No & \multicolumn{1}{|c|}{$\begin{array}{c}\text { Judul/ Isi } \\
\text { pemberitaan: } \\
\text { waktu Pemberitaan }\end{array}$} & \multicolumn{1}{|c|}{$\begin{array}{c}\text { No } \\
\text { data }\end{array}$} & $\begin{array}{c}\text { Media } \\
\text { Massa } \\
\text { Online }\end{array}$ & \multicolumn{1}{|c|}{ Tersedia di laman } \\
\hline 1 & $\begin{array}{l}\text { Alasan Prabowo } \\
\text { Bela Ratna Sebelum } \\
\text { Kebohongan } \\
\text { Terungkap }\end{array}$ & D01 & Kompas & $\begin{array}{l}\text { https://nasional.kompas.com/re } \\
\text { ad/2018/10/05/10453301/alasa } \\
\text { n-prabowo-bela-ratna- } \\
\text { sarumpaet-sebelum- } \\
\text { kebohongan-terungkap }\end{array}$ \\
\hline 2 & $\begin{array}{l}\text { Prabowo Yakin ada } \\
\text { Motif Politik di Balik } \\
\text { Dugaan } \\
\begin{array}{l}\text { Penganiayan Ratna } \\
\text { Sarumpaet }\end{array}\end{array}$ & D02 & Kompas & $\begin{array}{l}\text { https://nasional.kompas.com/re } \\
\text { ad/2018/10/02/22483341/prabo } \\
\text { wo-yakin-ada-motif-politik-di- } \\
\text { balik-dugaan-penganiayaan- } \\
\text { ratna-sarumpaet }\end{array}$ \\
\hline 3 & $\begin{array}{l}\text { Pengacara: Ratna } \\
\text { Sarumpaet Tak } \\
\text { pernah Dibesuk Tim } \\
\text { Prabowo Selama } \\
\text { Ditahan }\end{array}$ & D03 & Detik News & $\begin{array}{l}\text { https://m.detik.com/news/berita } \\
\text { /4409174/pengacara-ratna- } \\
\text { sarumpaet-tak-pernah-dibesuk- } \\
\text { tim-prabowo-selama-ditahan }\end{array}$ \\
\hline 4 & $\begin{array}{l}\text { Kisah Prabowo } \\
\text { tertipu cerita Fiksi } \\
\text { Ratna Sarumpaet }\end{array}$ & D04 & Detik News & $\begin{array}{l}\text { https://m.detik.com/news/berita } \\
\text { /4241423/kisah-prabowo- } \\
\text { tertipu-cerita-fiksi-ratna- } \\
\text { sarumpaet }\end{array}$ \\
\hline 5 & $\begin{array}{l}\text { Beredar Surat Ratna } \\
\text { Sarumpaet untuk }\end{array}$ & D05 & Bangka Pos & $\begin{array}{l}\text { http://bangka.tribunnews.com/a } \\
\text { mp/2018/10/04/beredar-surat- } \\
\text { ratna-sarumpaet-untuk- }\end{array}$ \\
\hline
\end{tabular}




\begin{tabular}{|l|l|l|l|l|}
\hline & $\begin{array}{l}\text { Prabowo Subianto- } \\
\text { Sandiaga Uno, Ini }\end{array}$ & & $\begin{array}{l}\text { prabowo-subianto-sandiaga- } \\
\text { uno }\end{array}$ \\
\hline 6 & $\begin{array}{l}\text { Ratna Sarumpaet } \\
\text { Umbar Senyum saat } \\
\text { Dibawa Jaksa }\end{array}$ & D06 & Tribun news & $\begin{array}{l}\text { http://www.tribunnews.com/na } \\
\text { sional/2019/02/01/ratna- } \\
\text { sarumpaet-umbar-senyum-saat- } \\
\text { dibawa-jaksa }\end{array}$ \\
\hline
\end{tabular}

Data didapat pada rentang waktu bulan Oktober 2018- Januari 2019. Data yang berupa teks dianalisis berdasarkan pendekatan Critical Discourse Analysis Norman Fairclough. Sedangkan keterkaitan konteks dengan budaya ideologi penguasa, alat legitimasi, dan kontrol dianalisis menggunakan ideologi.

CDA Norman Fairclough (sumber) menunjukan dan menginterpretasikan adanya penggunaan bahasa yang memiliki tujuan untuk menunjukan dan menginterpretasikan adanya hubungan antara tatanan atau pola-pola dengan tujuan yang diekspresikan. Artinya bila disederhanakan akan terbentuk pola pemilihan diksi dihubungkan dengan muatan koherensi dan kohesi yang akhirnya membentuk pemahaman wacana dimasyarakat.

D01 "Alasan Prabowo Bela Ratna Sebelum Kebohongan Terungkap"

Data tersebut berbentuk kalimat majemuk bertingkat, apabila diuraikan menggunakan bahasa baku judul pemberitaan tersebut akan berbentuk kalimat "Prabowo memberikan alasan membela Ratna ketika kebohongan ratna belum terungkap". Pada judul tersebut terdapat tiga pemilihan diksi alasan, bela, sebelum, dan terungkap, peneliti menganggap diksi tersebut dipilih untuk memberikan efek yang berbeda kepada pembaca.

Pada Kamus Besar Bahasa Indonesia V (KBBI V) secara leksikal kata Alasan dikaitkan dengan konteks kalimat tersebut berada pada kelas kata nomina yang memiliki arti dasar bukti (keterangan) yang dipakai untuk menguatkan pendapat (sangkalan, perkiraan, dsb). Uraian arti tersebut memberikan penjelasan bahwa penulis judul berita ingin memberikan kohesi antara dua klausa yang menjadi gagasan pada judul tersebut. Klausa pertama pada judul berisi gagasan Prabowo membela ratna dan klausa kedua berisi gagasan sebelum kebohongan terungkap. Diksi tersebut memberikan sebuah gambaran kepada pembaca bahwa Prabowo yang dijadikan subjek memberikan sangkalan terhadap kasus kebohongan yang dilakukan oleh Ratna sarumpaet. Artinya penulis tersebut berupaya mengiring opini bahwa Prabowo itu keliru dan memerlukan dasar bukti (keterangan) atas kesalahan pembelaan yang dilakukan olehnya.

Diksi kedua yang dipilih adalah bela yang berasal dari kata membela dengan penghilangan awalan mem-, Hal tersebut dilakukan karena sifat bahasa jurnalistik memiliki sifat, komunikasi dan ringkas. Apabila dikaitkan dengan konteks kalimat, kata bela memiliki makna memihak untuk melindungi dan mempertahankan. Pada diksi ini kembali penulis menjadikan tokoh Prabowo sebagai Subjek dikaitakan dengan sikap membela Ratna Sarumpaet. Klausa yang terdapat kata "bela" sengaja disimpan diawal, hal ini dilakukan untuk memberikan efek psikologi yang berbeda kepada pemahaman pembaca. 
Diksi ketiga yang akan dianalisis adalah kata sebelum. Kata sebelum secara leksikal berada pada kelas kata keterangan yang memiliki arti ketika belum terjadi; lebih dahulu dari (suatu pekerjaan, keadaan, dsb). Pada kontek judul berita kata sebelum digunakan untuk menunjukan hubungan antara klausa, yaitu klausa Alasan Prabowo Bela Ratna dengan klausa Kebohongan Terungkap. Ada hal yang menarik pada diksi ini, penulis berita sengaja mengunakan kata sebelum agar masyarakat pembaca dengan tidak langsung memiliki pemikiran bahwa Subjek prabowo memiliki keterkaitan dengan kasus kebohongan yang dilakukan oleh Ratna Sarumpaet.

\section{D02 "Prabowo Yakin ada Motif Politik} di Balik Dugaan Penganiayan Ratna Sarumpaet"

Data D02 berbentuk kalimat tunggal, apabila dianalisis secara fungsi sintaksis kalimat ini diuraikan sebagai berikut. Prabowo sebagai subjek, yakin Ada sebagai predikat, Motif politik sebagai Pelengkap dan Di balik dugaan penganiayaan Ratna Sarumpaet sebagai keterangan.

Pada data ini peneliti mengkritisi sebuah frasa yang menurut peneliti menjadi kunci proses penggiringan opini kepada masyarakat. Frasa tersebut adalah yakin ada yang secara sintaksis berfungsi sebagai predikat. Frasa itu mengaitkan antara subjek Prabowo dan pelengkap motif politik. Pada konteks judul, penulis meyakini bahwa pihak Prabowo yakin bahwa kasus penganiayaan (yang sekarang bergulir menjadi kasus kebohongan) terdapat motif politik. Motif politik di sini sudah pasti melibatkan lawan politik pada ajang Pilpres 2019.
Pada data ini, penulis mencoba memberikan opini ke masyarakat bahwa Prabowo meyakini bahwa Ratna Sarumpaet benar-benar menjadi korban penganiayan, lalu pada kejadian ini prabowo menggunakan kasus ini untuk menyerang lawan politiknya, sebelum akhirnya kasus ini terungkap menjadi kasus kebohongan publik (hoak).

D03 "Pengacara: Ratna Sarumpaet Tak pernah Dibesuk Tim Prabowo Selama Ditahan"

Judul pemberitaan pada data D03 berbentuk kalimat langsung, artinya penulis berita mengutip secara langsung apa yang dituturkan oleh pengacara tokoh politik Ratna Sarumpaet. Pada data ini terlihat ada proses pengiringan opini oleh penulis berita. Penggiringan opini tersebut mengaitkan dua subjek tokoh politik, yaitu Ratna Sarumpaet dengan Prabowo.

Frasa "Tak pernah dibesuk" menjadi penanda lahirnya konteks hubungan antara Prabowo dan Ratna Sarumpaet. Frasa tersebut terlihat, terdiri dari dua gagasan kata, yaitu tak pernah dan dibesuk. Kata dibesuk berdasarkan KBBI memiliki makna leksikal melakukan kunjungan ke rumah sakit untuk menjenguk orang sakit yang dirawat. Pada konteks judul berita ini adalah kunjungan ke tahanan/ lembaga permasyarakatan. Berdasarkan konteks dan budaya yang biasa terjadi, apabila terdapat seseorang yang sedang ditahan di lembaga pemasyarakat, lalu ada seseorang yang menjenguknya, sudah dipastika orang tersebut memiliki hubungan, baik itu saudara, rekan kerja atau bahkan orang yang berkepentingan.

Selain itu, judul pada data ini menjadi penguat tanda adanya hubungan timbal balik antara Ratna Sarumpaet sebagai korban dan Prabowo sebagai tokoh yang berada di balik kasus ini. 
Apabila dikaitkan dengan pribahasa yang berkembang di masyrakat Indonesia, judul pemberitaan ini sama dengan pribahasa "kacang lupa kulitnya"

D04 "Kisah Prabowo tertipu cerita Fiksi Ratna Sarumpaet"

Judul pemberitaan ini berbentuk kalimat tunggal, Pada data D04 yang menjadi butir analisis peneliti adalah kata kisah, tertipu, dan fiksi. Menurut peneliti kedua kata ini adalah sebagai kunci gagasan yang ingin disampaikan penulis judul. Pada data ini, diksi kisah dipilih untuk menjelaskan kepada publik tentang cerita perjalanan Prabowo tertipu oleh cerita fiksi Ratna Sarumpaet. Hal tersebut sejalan dengan pemaknaan secara leksikal kata kisah yaitu cerita tentang kejadian (riwayat dsb) dalam kehidupan seseorang dsb; kejadian (riwayat dsb)

Diksi kedua yaitu kata tertipu. Pemilihan diksi ini merupakan proses memaparkan sebuah kesimpulan yang akhirnya menjadi proses penggiringan opini. Bahwa pada kasus ini Prabowo sebagai subjek tertipu oleh Ratna Sarumpaet. Pada KBBI kata tertipu memiliki makna sudah ditipu; kena tipu, sedangkan kata tipu sendiri memiliki makna perbuatan atau perkataan yang tidak jujur (bohong, palsu, dsb) dengan maksud untuk menyesatkan, mengakali atau mencari untung; kecoh. Berkaitan dengan makna kontekstual pada diksi tertipu, yaitu yang berbohong adalah Ratna Sarumpaet dan yang dibohongi adalah Prabowo Subianto.

Diksi ketiga adalah fiksi yang secara kontekstual judul, tidak bisa dilepaskan dengan diksi cerita. Pada KBBI cerita fiksi dikategorikan sebagai cerita rekaan yang memiliki makna cerita yang sengaja dikarang oleh pengarangnya sebagai hasil khayalannya; cerita khayal; fiksi. Pada diksi ini selanjutnya penulis berita berupaya mengaitkan dengan diksi sebelumnya. Oleh karena itu dapat disimpulkan diksi kisah, tertipu dan fiksi apabila diuraikan menjadi sebuah gagasan bahwa "Prabowo bercerita tentang pengalaman (diksi kisah), tentang kebohongan yang menimpa dirinya, dilakukan untuk proses menyesatkan (diksi tertipu), dan kebohongan tersebut dibentuk oleh cerita rekaan yang dibuat oleh Ratna Sarumpaet (diksi fiksi).

D05 "Beredar Surat Ratna Sarumpaet untuk Prabowo Subianto-Sandiaga Uno"

Data D05 berbentuk kalimat majemuk bertingkat, dengan posisi klausa "Beredar Surat Ratna Sarumpaet" sebagai klausa atasan dan "untuk Prabowo Subianto-Sandiaga Uno, Ini" sebagai klausa bawahan. Pada judul pemberitaan ini, penulis memberikan asumsi terdapat hubungan antara Ratna Sarumpaet dengan kedua Capres (Prabowo dan Sandiaga uno).

Pada data ini yang menjadi fokus analisis adalah kata beredar, surat dan untuk. Kata surat pada KBBI memiliki makna leksikal kertas dsb yang bertulis (berbagai-bagai isi maksudnya). Hal tersebut menjadi persoalan tentang isi surat tersebut, selain itu opini lain yaitu sebuah pertanyaan "mengapa dalam bentuk surat?" Ketika dua orang atau lebih saling mengirim surat, berarti ada sesuatu yang tidak ingin diketahui orang lain.

Selanjutnya diksi kedua, kata untuk memiliki makna leksikal kata depan untuk menyatakan bagi. Pada konteks ini yang memberikan adalah Ratna Sarumpaet dan yang menerima adalah Prabowo Subianto. Terakhir, pemilihan diksi beredar menjadi kunci 
dari penggiringan publik terhadap judul berita ini. Kata beredar pada masyarakat Indonesia memiliki makna yang negatif. Artinya, sesuatu yang disembunyikan, karena isi atau hal yang ada di dalamnya tidak baik dan tidak untuk diketahui oleh masyarakat luas.

D06 "Ratna Sarumpaet Umbar Senyum saat Dibawa Jaksa"

Data D06 ini berbentuk kalimat tunggal, hal ini terlihat pada frasa umbar senyum yang menjadi frasa pengisi fungsi predikat pada kalimat ini. Pada judul ini terdapat sebuah pengiringan opimi, terlihat pada beberapa diksi yang selanjutnya menjadi keterkaitan dengan diksi selanjutnya. Pada data tersebut frasa umbar senyum dibangun berdasaran diksi yang menimbulkan makna secara kontekstual dengan kasus yang sedang dijalani oleh Ratna Sarumpaet. Kata umbar pada KBBI bermakna 1. $n$ membiarkan lepas (bebas); 2. $v$ membiarkan berbuat sekehendak hatinya, sedangkan kata senyum memiliki makna $n$ gerak tawa ekspresif yang tidak bersuara untuk menunjukan rasa senang, gembira, suka, dsb dengan mengembangkan bibir. Pada kontek ini terlihat dua gagasan yang menimbulkan makna saling bertolak belakang. Gagasan tersebut terlihat pada konteks sedang mengalami masalah hukum, tetapi masih bisa mengumbar senyum kepada publik.

Pada data ini terlihat pengiringan publik, tentang sikap tokoh politik Ratna Sarumpaet yang tetap merasa senang (tidak merasa bersalah akan kasus yang sedang menimpanya). Bahkan menyempatkan untuk memperlihatkan kepada masyarakat (mengumbar).

\section{SIMPULAN}

Berdasarkan hasil analisis data, peneliti menarik simpulan bahwa dalam proses pembuatan judul berita media online memiliki kontruksi tertentu. Pembuat judul berita sengaja menggunakan diksi yang memiliki banyak referen dalam proses pemaknaannya. Hal ini terlihat pada beberapa data yang telah penulis paparkan pada proses analisis data. Bahkan, beberapa diksi pada data ditampilkan dalam judul dan isi secara langsung membawa muatan politis tertentu.

Kontruksi media massa online pada pemberitaan politisi wanita Ratna sarumpaet menunjukkan terdapat upaya penggiringan opini terhadap masyarakat tentang keterlibatan salah satu paslon dengan kasus hoaks yang dilakukan oleh tokoh politik ratna sarumpaet. Hal ini dilakukan untuk menurunkan dukungan politik jelang pemilihan presiden 2019 .

\section{DAFTAR PUSTAKA}

Ansori, D. (2017). Analisis Wacana Teori, Aplikasi dan Pembelajaran. Bandung: Upi Press

Brown, G. dan Yule, G. (1996). Analisis Wacana. Jakarta: Gramedia Pustaka Utama

Fiske, J. (1990). Introduction to Communication Studies (Second Edition). London and New York: Routledge.

Kress, G. (1984). Linguistik and Ideological Transformations in News Reporting: Language, Image, Media (Davis, H. Walton, P., eds). England: Basic Blackwell.

Setiawan, B. (2011). Analisis Wacana Kritis Pemberitaan Kekerasan Berbasis Gender: Jurnal Ilmiah Komunikasi, 2(1).

Sorensen, A. S. dan Krolokke, C. (2006). Gender

Communication 
Theories and Analyses. Wibowo, W. (2009). Menuju Jurnalisme Thousand Oaks. California: Sage beretika, Peran bahasa, Bisnis, Publications, Inc. dan Politik di Era Mondial. Jakarta: Kompas. 